\title{
LONICERA CAERULEA L. AS A SOURCE OF BIOLOGICALLY ACTIVE COMPOUNDS FOR THE ENRICHMENT OF FERMENTED MILK PRODUCT
}

\author{
Dalija Seglinaa ${ }^{1, \#}$, Inta Krasnova ${ }^{1}$, and Sanita Alsiṇa ${ }^{2}$ \\ ${ }^{1}$ Institute of Horticulture, 1 Graudu Str., Ceriṇi, Krimūnu civil parish, Dobele Municipality, LV-3701, LATVIA \\ 2 Rīga Stradinš University, 16 Dzirciema Str., Rīga, LV-1007, LATVIA \\ \# Corresponding author, dalija.seglina@ @lu.Iv
}

Contributed by Dalija Segliṇa

\begin{abstract}
Lonicera caerulea L., also known as honeysuckle berries, are rich in biologically active compounds, which makes them a valuable raw material for the development of functional foods. The objects of the research were three honeysuckle cultivars ('Zoluška', 'Sinaja Ptica', 'Goluboje Vereteno'), four genotypes (No 2A; No 3; No 5; No 8) and kefir, enriched with various amounts (3-10\%) of fruit puree. Physical and chemical analyses to determine the qualitative indicators of raw materials and products were performed. The degree of liking of kefir was assessed using sensory analysis: hedonic and line scales. The results obtained showed that among the cultivars the highest content of anthocyanins (1103.5 mg.100 g ${ }^{-1}$ ), total phenols (693.3 mg.100 g $\left.{ }^{-1}\right)$, flavonoids (753.9 mg. $\left.100 \mathrm{~g}^{-1}\right)$, and tannins $\left(1.6 \mathrm{mg} \cdot 100 \mathrm{~g}^{-1}\right)$, were found in 'Sinaja Ptica' berries, while among the genotypes, berries of No 8 had the highest concentration of the aforesaid compounds. Both samples also showed the highest antiradical activity: ABTS ${ }^{+\bullet}$ on average by $71.7 \%$ and $\mathrm{DPPH}$ by $43.7 \%$. According to the sensory evaluation, kefir with $10 \%$ honeysuckle puree was rated the highest. Honeysuckle berries could be used as a promising source of natural antioxidants in future research aimed at developing different new products that could meet consumer expectations.
\end{abstract}

Keywords: honeysuckle berries, phenolics, anthocyanins, antiradical activity, kefir.

\section{INTRODUCTION}

Fruits and berries are an essential part of a healthy diet. Berries are low in calories, rich in fibre, many contain ascorbic acid and are rich in antioxidants, especially anthocyanins, which are found with other classes of phenolic compounds, including ellagitannins, flavan-3-ols, procyanidins, flavonols and hydroxybenzoates (Auzanneau et al., 2018; Güner et al., 2019). The juice, puree, and jam from dark berries (chokeberry, blueberry, honeysuckle) are high in polyphenol and flavonoid concentrations, they have potential intervention value for a number of chronic diseases such as diabetes, cardiovascular diseases, oxidative stress-related diseases such as neurodegenerative diseases and cancer prevention (Douglas et al., 2017; Becker and Szakiel, 2019). Blue honeysuckle (Lonicera caerulea L.), also known as haskap, is a perennial berry shrub of the Caprifoliaceae family. It is increasingly cultivated in many countries (commonly planted in eastern Europe, Russia, Canada, Japan, and Asia) due to its pronounced taste, shrub fertility and the content of biologically active compounds in the berries as well as low requirements for soil quality and climate (Grobelna et al., 2019). The fruits of $L$. caerulea have a long history of being used in traditional medicine as a remedy for gastrointestinal disorders, bacterial infections and hypertension (Jurikova et al., 2012; Gołba et al., 2020). The berries are rich in biologically active compounds and the high content of anthocyanins (the major bioactive anthocyanin of honeysuckle is cyanidin-3-O-glucoside), phenolic compounds, vitamins and minerals makes them a valuable raw material for the development of functional foods $(\mathrm{Ru}-$ pasinghe et al., 2018; Sharma and Lee, 2020). Compared with other berries, it should be noted that honeysuckle berries are among the earliest fruits in the season, and as the 
first ones, the earliest varieties ripen at the end of May. They can play an important role in enriching our diet during the spring season. The honeysuckle berry market in Europe has so far been limited by legislation. Only from 2018 were they were included in the list of the Novel Food Catalogue (EU Novel Food Catalogue...), which will significantly promote the wider use of berries, both fresh and processed.

Fermented milk products are an excellent matrix for the inclusion of ingredients or additives that make the final product functional due to their specific properties (Farag et al., 2020; García-Burgos et al., 2020). Kefir contains many species of lactic acid bacteria and yeasts that are already known for their probiotic properties, and it has long production traditions in Eastern Europe with supposedly beneficial health effects, where it is used for patients in hospital and is recommended for infants (Nielsen et al., 2014). Intake of probiotics and lactic acid bacteria, especially in fermented foods, leads to significant positive improvements in balancing intestinal permeability and barrier function. It has been shown to have direct effects on metabolic syndrome, atherosclerosis, inflammatory bowel diseases, and colon cancer (Bell et al., 2018; Bellikci-Koyu et al., 2019). Increasing consumer demand for healthy foods has prompted the efforts to develop new products with defined health benefits; an example is hawthorn puree additive to kefir, which increases its antioxidant properties (Aiello et al., 2020).

Although L. caerulea is a relatively new fruit on the market, it turns out to have good prospects, as was concluded by growers in Poland (Fruit Growers News...), where the area of honeysuckle cultivation currently exceeds 2000 ha. There is also interest in these berries among growers in the Baltic States, including Latvia. Therefore, in order to provide more knowledge to growers and consumers, a study was conducted in which: 1) the concentration of biologically active substances in various honeysuckle cultivars and genotypes was determined; and 2) the use of honeysuckle puree for the enrichment of kefir was tested.

\section{MATERIALS AND METHODS}

Research objects. The objects of the research were:

1) three honeysuckle (Lonicera caerulea L.) cultivars ('Zoluška', 'Siņaja Ptica', 'Goluboje Vereteno') and four genotypes (seedlings: No 2A; No 3; No 5; No 8) grown at the Institute of Horticulture, Dobele, Latvia (GPS coordinates: $56.6115^{\circ} \mathrm{N}, 23.2961^{\circ} \mathrm{E}$ ). The berries were harvested in the last week of May (2019), immediately chilled, packed in plastic boxes suitable for freezing and frozen at $-18{ }^{\circ} \mathrm{C}$, where they were stored two months until analysis.

2) kefir ("Limbažu kefīrs") was purchased in a store and used on the same day. The kefir samples were enriched with various amounts $(3 \% ; 5 \% ; 7 \% ; 10 \%)$ of honeysuckle puree. A blended mixture of thawed honeysuckle berry samples was used.
Physical and chemical analyses. Soluble solids, $\mathrm{pH}$, total titratable acidity, total phenolic compounds, tannins, flavonoids, anthocyanins, vitamin $\mathrm{C}$, antiradical activity, colour were determined and sensory evaluation was conducted to determine the qualitative indicators of honeysuckle berries and kefir.

Soluble solids (SSC) content (Brix\%) determination in fruits and products was done using the refractometric method according to standard: ISO 2173:2003; measured with a handheld digital refractometer (PAL-1; ATAGO Co., Ltd., Tokyo, Japan).

$\underline{\mathrm{pH}}$ was determined using a pH meter 3510 (Jenway, England).

Total titratable acidity (TTA) of honeysuckle berries was assessed for ten millilitres of filtered berry fruit water extracts, which was titrated with $0.1 \mathrm{~mol} \cdot \mathrm{l}^{-1} \mathrm{NaOH}$ to a $\mathrm{pH}$ of 8.1 according to general guidelines on objective tests (OECD, 2018). TTA was expressed as percent citric acid equivalent in fresh weight $(\mathrm{FW})$.

Titratable acid (TA) of kefir was determined by titrating a mixture of kefir and sterile water $(2: \mathrm{v} / \mathrm{v})$ with $0.1 \mathrm{~mol} \cdot \mathrm{l}^{-1}$ $\mathrm{NaOH}$ using $0.1 \%(\mathrm{w} / \mathrm{v})$ phenolphthalein solution in alcohol, according to the standard LVS ISO 6092:2003. The TA values were expressed as \% lactic acid equivalent $/ \mathrm{FW}$.

Colour of kefir, enriched with various amounts of frozen honeysuckle puree, was measured in a CIE L*a*b* colour system using an Tristimulus Colorimeter, measuring colour parameters with a CM 2500c (Japan) in six repeclations for each sample and expressed as Chroma values, calculated by the formula as reported by Du and Myracle (2018).

Total phenols (TP) concentration was determined by the photometric method using Folin-Ciocalteu reagent by Singleton et al. (1999), and expressed as gallic acid equivalents (mg GAE.100 $\mathrm{g}^{-1} \mathrm{FW}$ ).

Total flavonoids (TF) concentration was determined by the photometric method using aluminium chloride complex forming assay by Arina et al. (2013), and expressed as catechin equivalents (mg CAE. $100 \mathrm{~g}^{-1} \mathrm{FW}$ ).

The total tannin (TT) concentration was estimated by the method of Price and Butler (Paaver et al., 2010), and expressed as mg tannin acid equivalents (mg TAE.100 $\mathrm{g}^{-1}$ FW).

The total anthocyanins (TANC) concentration was determined by the photometric method described by Wrolstad (1993), and expressed by cyanidin-3-o-glucoside equivalents (mg CGE.100 $\mathrm{g}^{-1} \mathrm{FW}$ ).

Vitamin $\mathrm{C}$ was determined by high performance liquid chromatography (Shimadzu, Kyoto, Japan) according to standard LVS EN 14130:2003.

The antioxidant activity (AOA) by radical scavenging activity method using 2, 2-diphenyl-1-picrylhydrazyl (DPPH' as- 
say) was determined according to Brand-Williams et al. (1995) with minor modifications. Briefly, the test sample $(100 \mathrm{ml})$ was reacted with $2.9 \mathrm{ml}$ of $\mathrm{DPPH}^{-}$solution (0.0039 $\mathrm{g} \mathrm{DPPH}^{-}$in $100 \mathrm{ml}$ ethanol). Absorbance of the sample was done at $515 \mathrm{~nm}$ using a spectrophotometer (UV probe 1800 , Shimadzu). The radical scavenging activity of the sample was expressed as \% inhibition of $\mathrm{DPPH}^{-}$absorbance:

The AOA by radical scavenging activity method using ABTS $^{+\bullet}$ (2,2'-azino-bis (3-ethylbenzothiazoline-6-sulfonic acid) radical cation decolourisation assay was performed using a spectrophotometric method described by Miliauskas $e t$ al. (2004) with minor modifications. Briefly, three $\mathrm{ml}$ of $\operatorname{ABTS}^{+\bullet}$ cation solution were mixed with $30 \mu \mathrm{l}$ ethanol extract solution in a $1-\mathrm{cm}$ path length $3 \mathrm{ml}$ cuvette and the decrease of absorption was measured at $734 \mathrm{~nm}$ for $10 \mathrm{~min}$ utes.

Sensory analyses of kefir enriched with honeysuckle puree were conducted using a 9-point hedonic scale and line scale (sensory attributes: colour and appearance, taste, acidity, aftertaste) according to ISO 4121:2003, Sensory AnalysisGuidelines for the use of quantitative response scales. Twenty trained and experienced panellists from the Institute of Horticultural in the evaluation of products were involved.

Statistical analysis. Experimental data processing was carried out by one-way (berries and kefir samples) analysis with replication of variance (ANOVA), using the SPSS 23 software package. The mean value, percentage and standard deviation were calculated for the obtained results. Closeness of the relationship between the parameters was determined by analysis of the Pearson correlation coefficient, and Tukey's multiple range test was used to clarify significant differences $(p<0.05)$ among the studied samples.

\section{RESULTS}

The chemical parameters of the tested honeysuckle berries samples are shown in Table 1 and Figure 1. The results indicated that there were significant differences between samples in all chemical indices (soluble solids content and total titratable acidity $p=0.018$, vitamin $\mathrm{C}$, total tannin, flavonoid, anthocyanins, and phenols $p<0.001$ ). The soluble solids concentration varied from 12.5 Brix \% ('Sin,aja Ptica') to $16.2 \mathrm{Brix} \%$ (No 8), total titratable acidity (TTA) from $1.0 \%$ ('Zoluška') to $1.6 \%$ (No 5) and pH was in the range of 2.7-3.0. Total tannin (TT) concentration in the honeysuckle genotype No 5 berries was two times higher $(1.6 \mathrm{mg}$ TAE. $\left.100 \mathrm{~g}^{-1}\right)$ than in 'Sinaja Ptica' (0.8 mg TAE.100 g $\left.{ }^{-1}\right)$. The analysed honeysuckle berries were rich in flavonoids and anthocyanins, and their concentration in the samples differed significantly. The highest TF and TANC concentra-

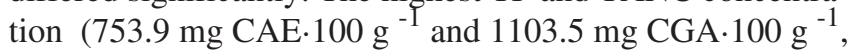
respectively) was found in 'Sinaja Ptica' berries. A strong positive correlation was found between total flavonoid and total anthocyanin concentration (Table 2). The concentra-

Table 1. Chemical compounds in honeysuckle berries

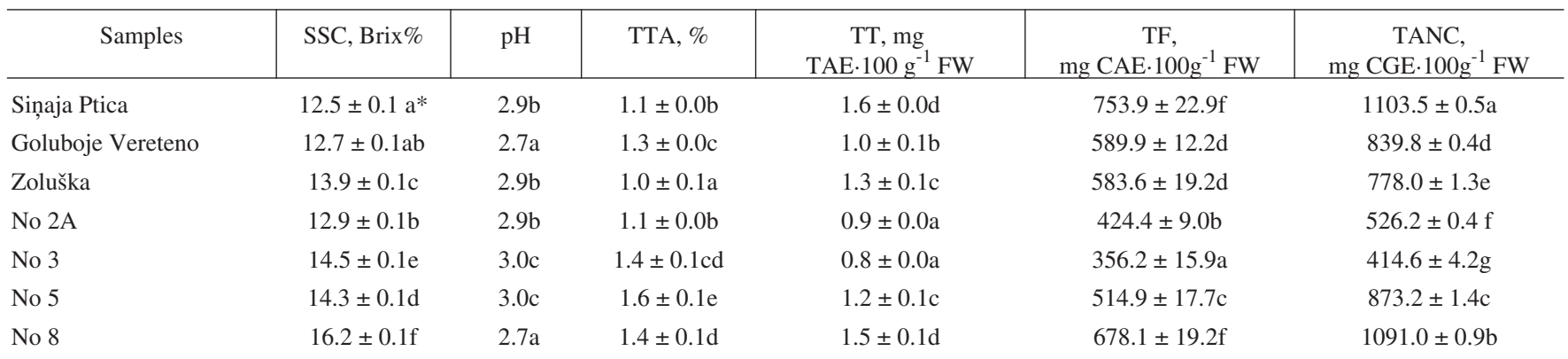

Mean and standard deviations are given $(n=4)$. SSC, soluble solid concentration; TTA, total titratable acidity; TT, total tannin; TF, total flavonoids; TANC, Total anthocyanins.

* values, marked with the same letters in a column, are not significantly different $(p>0.05)$.

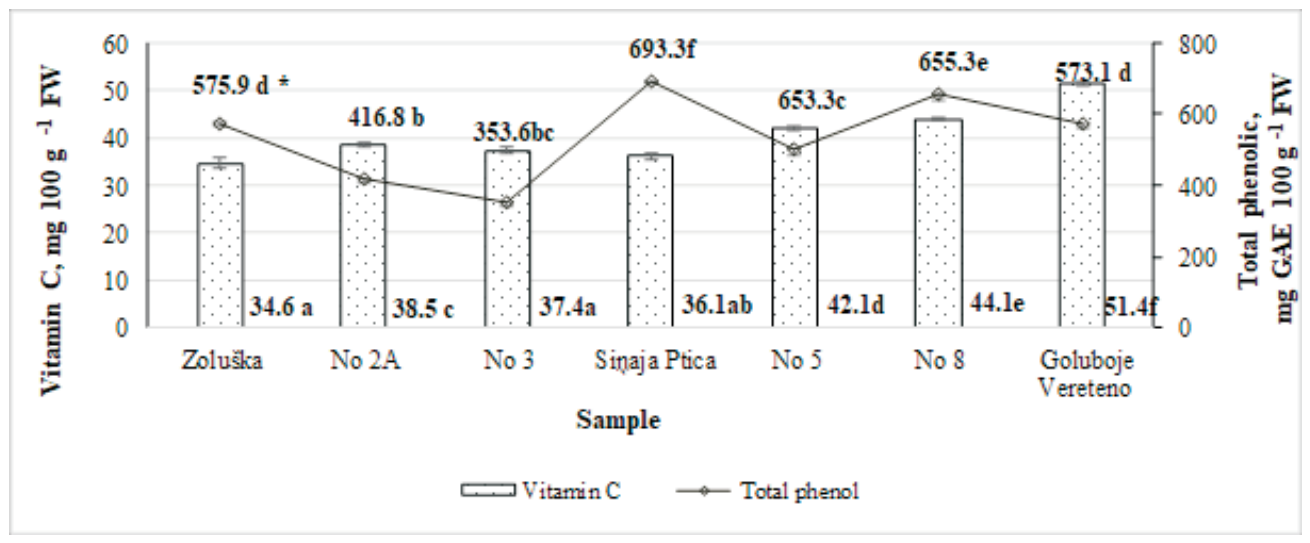

Fig. 1. The concentration of vitamin $\mathrm{C}$ and total phenolics in honeysuckle berry. The mean data are indicated by standard deviations ( $\mathrm{n}=$ 4). * values, marked with the same letters in a figure, are not significantly different $(p>0.05)$. 
Table 2. Pearson's correlation coefficient

\begin{tabular}{|l|l|l|l|l|l|l|l|}
\hline & TT & SSC & pH & Vit C & TF & TP & \\
\hline Vit C & & & $-0.691^{* *}$ & & & \\
\hline TA & & $0.502^{* *}$ & & $0.506^{* *}$ & & \\
\hline TANC & $0.941^{* *}$ & & $-0.493^{* *}$ & & $0.947^{* *}$ & $0.949^{* *}$ \\
\hline TF & $0.924^{* *}$ & & $-0.525^{* *}$ & & & \\
\hline TP & $0.920^{* *}$ & & $-0.567^{* *}$ & & $0.994^{* *}$ & \\
\hline DPPH & $0.920^{* *}$ & & $-0.418^{* *}$ & & $0.919^{* *}$ & $0.922^{* *}$ \\
\hline ABTS $^{+\bullet}$ & $0.812^{* *}$ & & $-0.609^{* *}$ & $0.373^{*}$ & $0.924^{* *}$ & $0.964^{* *}$ & $0.942^{* *}$ \\
\hline
\end{tabular}

** Correlation is significant at the 0.01 level

* Correlation is significant at the 0.05 level

TT, total tannin; SSC, soluble solids concentration; Vit C, vitamin C, TF, total flavonoids; T, total phenols; TANC, total anthocyanins; DPPH', ABTS ${ }^{+}$, antioxidant activity

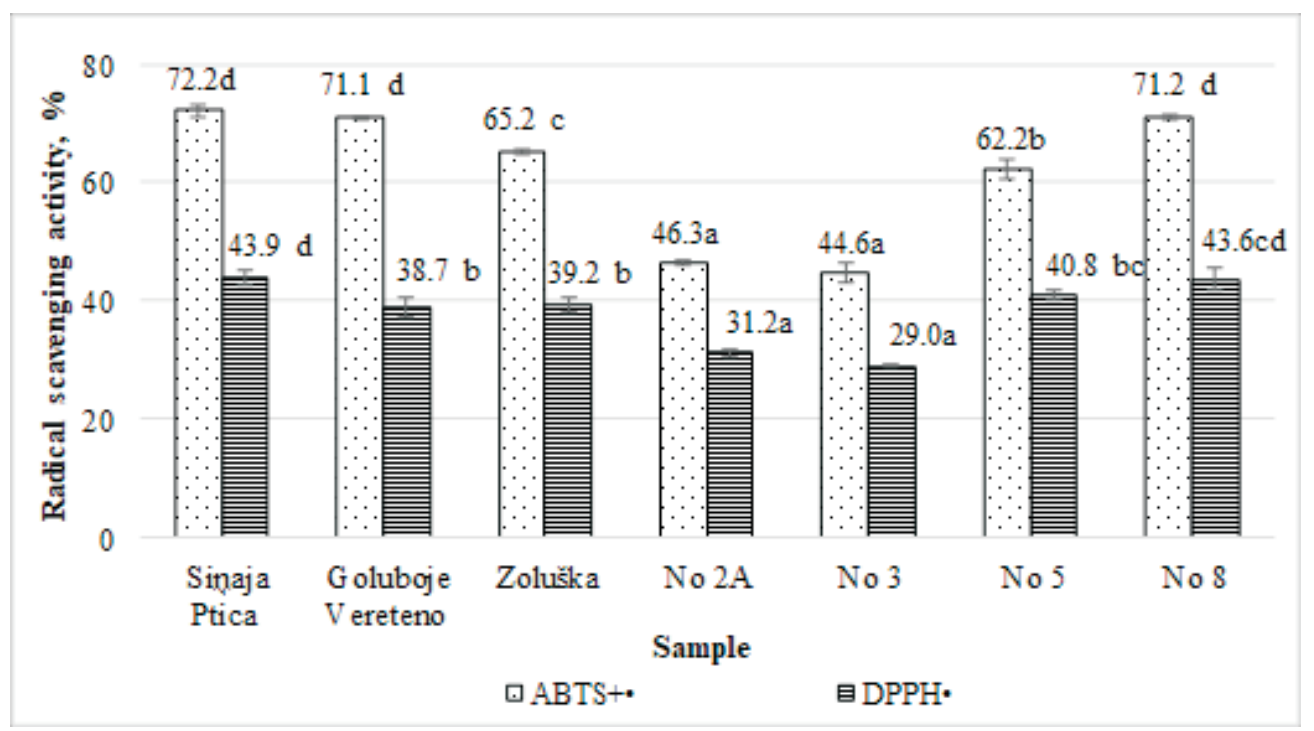

Fig. 2. Radical $\left(\mathrm{ABTS}^{+\bullet}\right.$, DPPH') scavenging activity assays for the honeysuckle berry. The mean data are indicated by standard deviations $(\mathrm{n}=4) . *$ values, marked with the same superscript letters in a figure, are not significantly different $(p>$ $0.05)$.

tion of vitamin $\mathrm{C}$ in berries was not high and varied from 34.6 to $51.4 \mathrm{mg} \cdot 100 \mathrm{~g}^{-1}$. The berries contained a significant amounts of phenolic compounds (TP), and depending on the sample, the TP concentration ranged from $353.6 \mathrm{mg}$ GAE.100 g $\mathrm{g}^{-1}$ (genotype No 3) to $693.3 \mathrm{mg}$ GAE.100 g ('Sinaja Ptica') (Fig. 1). The antioxidant activity (DPPH' and $\mathrm{ABTS}^{\mathbf{+}^{\bullet}}$ ) of the blue honeysuckle berries of seven cultivars and genotypes is shown in Figure 2. The effects of different compounds present in the berries on the antioxidant activity measured by the $\mathrm{DPPH}^{-}$assay ranged from $29 \%$ to $43.9 \%$, and for the $\mathrm{ABTS}^{+\bullet}$ assay from $44.6 \%$ to $72.2 \%$. The results obtained indicated significant differences between the antioxidant potentials of samples $\left(\mathrm{ABTS}^{+^{*}}, p=\right.$ 0.002; $\left.\mathrm{DPPH}^{-} p=0.035\right)$.

There was: 1) moderate negative correlation between $\mathrm{pH}$ parameters and vitamin $\mathrm{C}, \mathrm{TANC}, \mathrm{TF}$ and TP; 2 ) a strong positive correlation between TP and TF concentration ( $\mathrm{r}=$ $0.994)$, and between TT and TANC ( $\mathrm{r}=0.941)$, TF $(\mathrm{r}=$ $0.924)$, and TP $(r=0.920)$. The antioxidant activity (by $\mathrm{ABTS}^{+\bullet}$, $\mathrm{DPPH}^{-}$) was strongly correlated with TT, TF, TP, and TANC concentration, and there was a medium correlation $(\mathrm{r}=0.373)$ between $\mathrm{ABTS}^{+\bullet}$ and vitamin $\mathrm{C}$ concentration. Correlation coefficients were higher for the $\mathrm{DPPH}^{-}$ method with TT $(r=0.920)$ than the $\operatorname{ABTS}^{+\bullet}(r=0.812)$ (Table 2). The results of the physical and chemical indicators of the kefir samples enriched with various amounts $(3 \% ; 5 \% ; 7 \% ; 10 \%)$ of honeysuckle berries puree are shown in Table 3. The addition of honeysuckle puree to kefir has a significant effect on quality indicators, increasing the amount of puree also proportionally increases the total anthocyanin, tannin, titratable acidity, as well as vitamin $\mathrm{C}$ and total phenolic content (Fig. 3). The high content of anthocyanins in the berries and the acidity of kefir created an intense colour; the red color ( + a value) for the kefir after adding honeysuckle puree was gradually higher in samples: K3 by $17 \%$, K5 by $71 \%, \mathrm{~K} 7$ by $79 \%$ and K10 by $86 \%$. A statistically significant difference $(p<0.05)$ between all examined and calculated parameters: colour, chroma, TANC, TA, TT, SSC, TP, and vitamin C was observed. Figure 4 illustrates radical $\left(\mathrm{DPPH}^{-}\right.$and $\mathrm{ABTS}^{\mathbf{+}^{\bullet}}$ ) scavenging antioxidant activity assay inhibition for kefir and for kefir enriched with honeysuckle berry puree. The antioxidant activity gradually increased with berry amount and was statistically significant $(p<0.05)$ between samples. Food sensory properties are important quality control criteria. The sensory evaluation results of kefir with honeysuckle berry puree are shown in Figure 5. The value of hedonic evaluation in- 
Table 3. Chemical compounds in kefir enriched with honeysuckle berry puree

\begin{tabular}{|c|c|c|c|c|c|c|c|c|}
\hline \multirow{2}{*}{ Sample } & \multicolumn{4}{|c|}{ Colour value $(n=6)$} & \multicolumn{4}{|c|}{ Chemical parameters $(n=4)$} \\
\hline & $1^{*}$ & $a^{*}$ & $\mathrm{~b}^{*}$ & Chrome & $\begin{array}{c}\text { TANC, mg } \\
\text { CGE. } 100 \mathrm{~g}^{-1}\end{array}$ & TA, $\%$ & $\begin{array}{c}\text { TT, } \mu \mathrm{g} \\
\text { TAE } 100 \mathrm{~g}^{-1}\end{array}$ & SSC, Brix \% \\
\hline K3 & $63.4 \pm 0.4$ & $10.6 \pm 0.1$ & $0.4 \pm 0.1$ & 10.6 & $4.1 \pm 0.1$ & $0.78 \pm 0.01$ & $17.0 \pm 0.3$ & $7.3 \pm 0.1$ \\
\hline K5 & $62.6 \pm 0.3$ & $14.9 \pm 0.1$ & $-0.9 \pm 0.1$ & 14.9 & $5.9 \pm 0.1$ & $0.81 \pm 0.00$ & $24.1 \pm 0.2$ & $7.5 \pm 0.0$ \\
\hline K7 & $58.9 \pm 0.4$ & $18.7 \pm 0.2$ & $-1.2 \pm 0.1$ & 18.7 & $8.0 \pm 0.1$ & $0.86 \pm 0.00$ & $31.0 \pm 0.1$ & $7.6 \pm 0.0$ \\
\hline K10 & $48.5 \pm 0.2$ & $21.7 \pm 0.0$ & $-0.5 \pm 0.1$ & 21.7 & $10.1 \pm 0.1$ & $0.90 \pm 0.00$ & $38.7 \pm 0.1$ & $7.8 \pm 0.1$ \\
\hline Kefir & $72.2 \pm 0.1$ & $-1.8 \pm 0.0$ & $6.7 \pm 0.1$ & 6.9 & - & $0.75 \pm 0.01$ & $5.5 \pm 0.1$ & $7.1 \pm 0.1$ \\
\hline
\end{tabular}

Mean and standard deviations are given. Samples: K3 (kefir $+3 \%$ of honeysuckle puree), K5 (kefir $+5 \%$ of honeysuckle puree), K7 (kefir $+7 \%$ of honeysuckle puree), K10 (kefir $+10 \%$ of honeysuckle puree). TANC, total anthocyanins; TA, titratable acidity; TT, total tannin; SSC, soluble solids concentration.
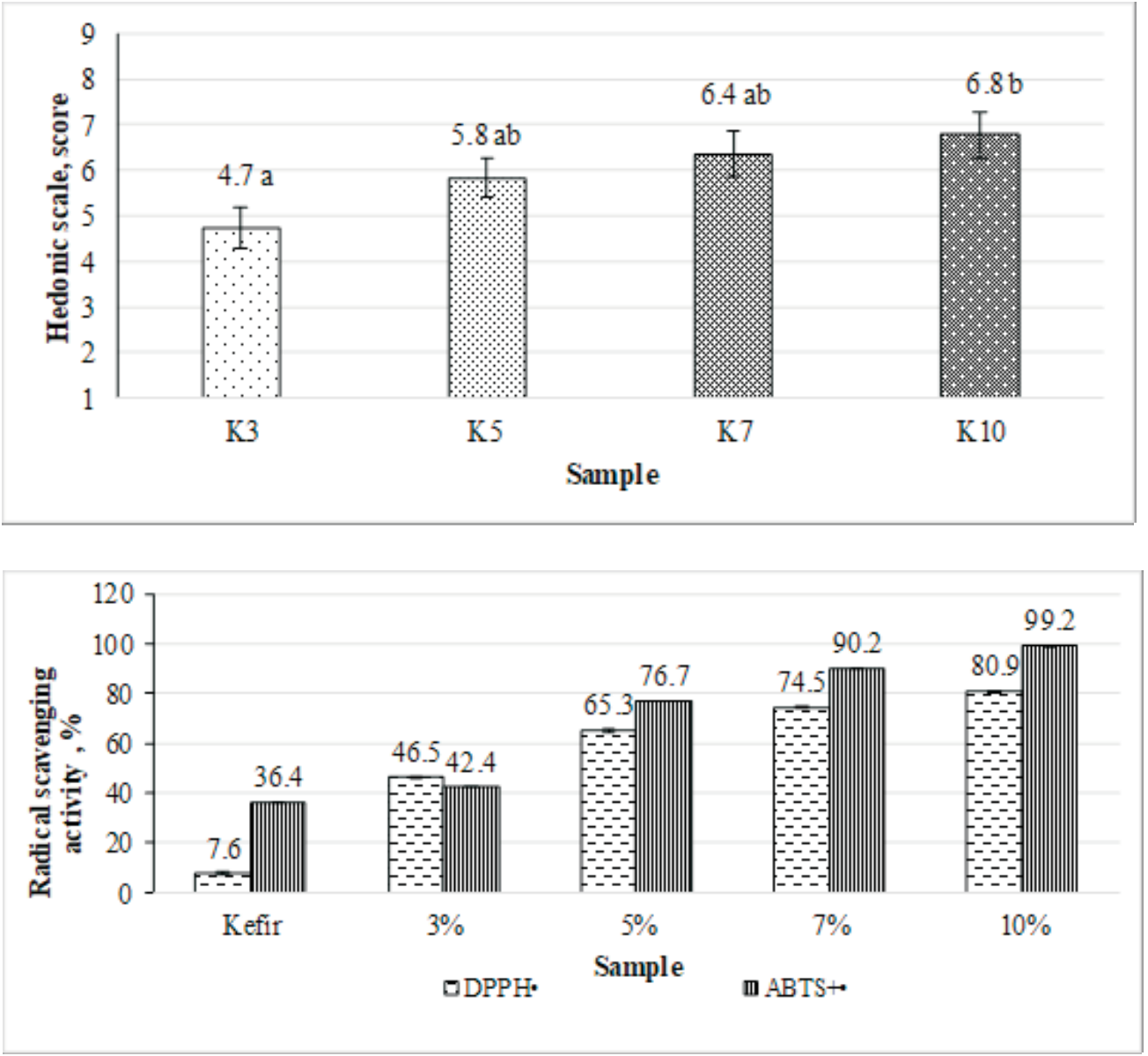

Fig. 3. Total phenolics and vitamin $\mathrm{C}$ in the kefir samples enriched with various amounts $(3 \% ; 5 \% ; 7 \%$; $10 \%)$ of honeysuckle puree. Samples: K3 (kefir $+3 \%$ of honeysuckle puree), K5 (kefir $+5 \%$ of honeysuckle puree), $\mathrm{K} 7$ (kefir $+7 \%$ of honeysuckle puree), K10 (kefir + $10 \%$ of honeysuckle puree) creased in proportion to the added amount of honeysuckle berry puree: from 4.7 - neither like nor dislike (sample K3) to 6.8 - moderately like (sample K10). Sensory properties of kefir samples: colour and appearance, taste, acidity, and aftertaste evaluated by line scale are shown in Figure 6. A statistically significant difference between sensory properties: colour + appearance, taste, aftertaste, and acidity (respectively, $p<0.001, p=0.014, p=0.021, p=0.045$ ) was observed for all samples.

\section{DISCUSSION}

The composition of biologically active compounds in honeysuckle berries depends on many factors, including place of cultivation, climatic conditions, variety and time of har- vest (Šenica et al., 2018; Grobelna et al., 2019; Gołba et al., 2020). Several results obtained in our study are comparable to those obtained in Slovakia (Jurikova et al., 2014; Fujita et al., 2020). In our sample, the vitamin C concentration ranged from $36.1-51.4 \mathrm{mg} \cdot 100 \mathrm{~g}^{-1}$, and the berries were not acidic as the titratable acidity was low (1.0-1.6\%). It was found that in 17 selected clones of honeysuckle berries grown in Slovakia, the vitamin $\mathrm{C}$ concentration ranged from 9.7 to $46.7 \mathrm{mg} 100 \mathrm{ml}$ juice, but the berries were more acidic 1.5-2.6\%. Sochor et al. (2014) in a study of the same varieties in the Czech Republic ('Goluboje Vereteno', 'Sinaja Ptica', 'Zoluška') found that the total phenol content in the berries was respectively, $8.7,7.6$, and $8.6 \mathrm{~g} \cdot \mathrm{kg}^{-1}$.

The most effective antioxidants found among phenolic compounds in berries are anthocyanins. The content of antho- 

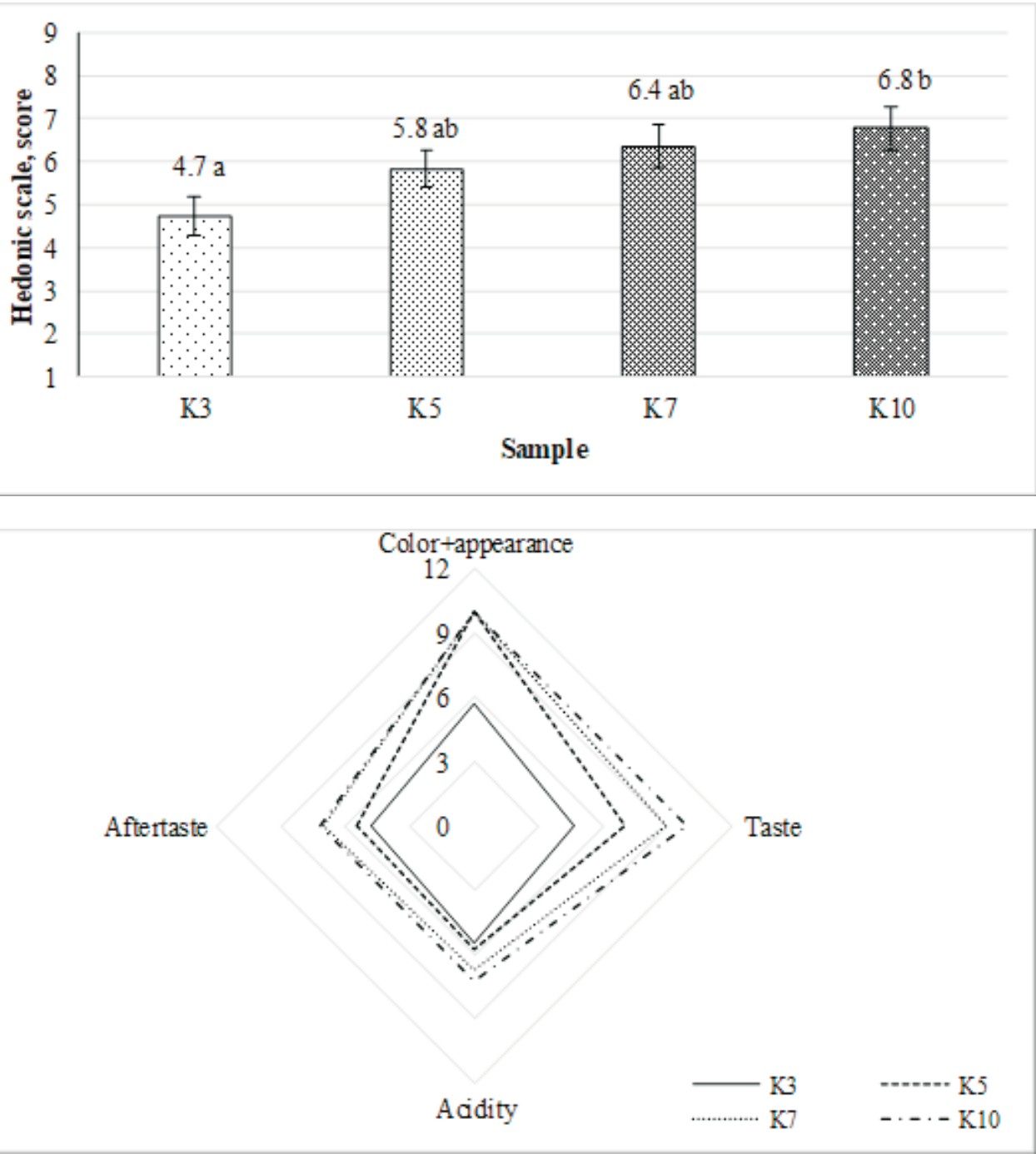

Fig. 5. Consumer acceptability (by 9-point Hedonic scale) of kefir samples enriched with various amounts $(3 \% ; 5 \% ; 7 \% ; 10 \%)$ of honeysuckle puree. Samples: K3 (kefir $+3 \%$ of honeysuckle puree), K5 (kefir $+5 \%$ of honeysuckle puree), K7 (kefir + $7 \%$ of honeysuckle puree), K10 (kefir $+10 \%$ of honeysuckle puree)

Fig. 6. Consumers evaluation of sensory attributes (by Line scale) of kefir enriched with various amounts $(3 \% ; 5 \% ; 7 \% ; 10 \%)$ of honeysuckle puree. Samples: K3 (kefir $+3 \%$ of honeysuckle puree), K5 (kefir $+5 \%$ of honeysuckle puree), K7 (kefir + $7 \%$ of honeysuckle puree), K10 (kefir $+10 \%$ of honeysuckle puree $)$ cyanins in honeysuckle berries is comparable to that in elderberry and chokeberry. Du et al. (2018) found that the concentration of total anthocyanins in chokeberry was 275.6 $\mathrm{mg} \mathrm{C} 3 \mathrm{G} \cdot 100 \mathrm{~g}^{-1}$ and $604.4 \mathrm{mg} \mathrm{GAE} \cdot 100 \mathrm{~g}^{-1}$ of total phenolic compounds; while in elderberry TANC was $416.9 \mathrm{mg}$ $\mathrm{C} 3 \mathrm{G} \cdot 100 \mathrm{~g}^{-1}$ and phenols $-369.5 \mathrm{mg} \mathrm{GAE} \cdot 100 \mathrm{~g}^{-1}$. Blackcurrant cultivars originating from Scotland, Lithuania, Latvia, Poland, and Finland (grown in Finland) contained high amounts of anthocyanins, with delphinidin and cyanidin derivatives being dominant in the berries (Tian et al., 2019).

Our studies showed that honeysuckle berries contained up to 9.2 times more total phenolic compared to different varieties of apples, which are one of the most commonly consumed fruits in the world. A cultivar effect can be relevant, as total polyphenol concentration ranged between 56 and $221 \mathrm{mg}$ GAE. $100 \mathrm{~g}^{-1}$ wet weight in 'Gala' and 'Panaida' red apple cultivars, respectively (Francini and Sebastiani, 2013). It can be concluded that the daily diet can be significantly enriched with biologically active substances by addition of even a small amount of honeysuckle berries.

A study to increase the nutritional value of kefir with chokeberry and elderberry juice was performed and chemical composition was evaluated by Du et al. (2018). It was found that with addition of $13 \mathrm{~g}$ chokeberry or $10 \mathrm{~g}$ elderberry juice to kefir products, the concentration of total anthocyanins was, respectively, 17.0 and $1.1 \mathrm{mg} \mathrm{CGE} \cdot 100$ $\mathrm{ml}^{-1}$ and total phenolics - 20.0 and $42.0 \mathrm{mg}$ GAE.100 $\mathrm{ml}^{-1}$, respectively. In another study, Nguyen (2016) found that the $a^{*}$ value of yogurt after the addition of $3 \%$ chokeberry juice increased from -1.5 to 1.3 , and that total phenolic concentration increased from 16.6 to $54.0 \mathrm{mg}$ $\mathrm{GAE} \cdot \mathrm{g}^{-1}$. It was concluded that colour changes and TP, TF, antioxidant activity increased proportionally with amounts of chokeberry juice added. Antioxidant activity of the fruit juice containing yogurt was significantly higher (by $\mathrm{DPPH}^{-}$ $77.8 \%$; by $\operatorname{ABTS}^{+\bullet} 70.1 \%$ ) in comparison to yogurt control sample without additives $(9.4 \%)$.

Tannins bind to proteins and carbohydrates, reducing the availability of calories and can benefit health in special diets aimed at weight losses. The downside of additional tannins is they can give the product a bitter and astringent taste (Queiroz et al., 2018). In our study, kefir enriched with $10 \%$ honeysuckle berry puree was expected to have a bitter taste, but the sensory evaluation showed the highest results. For further studies, it would be advisable to determine the stability of biologically active substances during storage of ke- 
fir, by evaluating both the $\mathrm{pH}$ and the lactic acid content of the product.

\section{CONCLUSIONS}

The highest concentration of anthocyanins (1103.5 mg.100 $\mathrm{g}^{-1}$ ), total phenols (693.3 mg.100 g $\mathrm{g}^{-1}$ ), flavonoids (753.9 $\left.\mathrm{mg} \cdot 100 \mathrm{~g}^{-1}\right)$, and tannins $\left(1.6 \mathrm{mg} \cdot 100 \mathrm{~g}^{-1}\right)$ was found in 'Sin,aja Ptica' berries, while 'Goluboje Vereteno' berries had the highest concentration of vitamin C (51.4 mg.100 $\mathrm{g}^{-1}$ ). Among the genotypes, No 8 berries were the most valuable: the concentration of anthocyanins was only lower by $2 \%$ and flavonoids by $10 \%$ than that of 'Sinaja Ptica' berries. Both samples also showed the highest antiradical activity. According to the sensory evaluation using the line scale, the sour milk product kefir with $10 \%$ honeysuckle puree was rated the highest. The honeysuckle berries could be used as a promising source of natural antioxidants in future research aimed at developing different new products that could meet consumer expectations.

\section{REFERENCES}

Aiello, F., Restuccia, D., Spizzirri, U. G., Carullo, G., Leporini, M., Loizzo, M. R. (2020). Improving kefir bioactive properties by functional enrichment with plant and agro-food waste extracts. Fermentation, 6 (3), 83.

Auzanneau, N., Weber, P., Kosińska-Cagnazzo, A., Andlauer, W. (2018). Bioactive compounds and antioxidant capacity of Lonicera caerulea berries: Comparison of seven cultivars over three harvesting years. J. Food Compos. Anal., 66, 81-89.

Arina, N. B., Rohman, A. (2013). The phenolic contents and antiradical activity of Indonesian Phyllantus urinaria L. Int. Food Res. J., 20 (3), 1119-1124.

Becker, R., Szakiel, A. (2019). Phytochemical characteristics and potential therapeutic properties of blue honeysuckle Lonicera caerulea $\mathrm{L}$. (Caprifoliaceae). J. Herb. Med., 16, 100237.

Bell, V., Ferróo, J., Pimentel, L., Pintado, M., Fernandes, T. (2018). One health, fermented foods, and gut microbiota. Foods, 7 (12), 1-17.

Bellikci-Koyu, E., Sarer-Yurekli, B. P., Akyon, Y., Aydin-Kose, F., Karagozlu, C., Ozgen, A. G., Brinkmann, A., Nitsche, A., Ergunay, K., Yilmaz, E., et al. (2019). Effects of regular kefir consumption on gut microbiota in patients with metabolic syndrome: A parallel-group, randomized, controlled study. Nutrients, 11 (9), 1-23.

Brand-Williams, W., Cuvelier, M. E., Berset, C. (1995). Use of a free radical method to evaluate antioxidant activity. Lebensm. Wiss. u.-Technol., 28, $25-30$

Douglas, W.W., Paul, N., Harpal Singh, B., Keith, G., Ram, S., Fabien De, M., Horiuchi, R., Takahashi, T. (2017). The role of food antioxidants, benefits of functional foods, and influence of feeding habits on the health of the older person: An overview. Antioxidants, 6 (4), 81.

Du, X., Myracle, A. D. (2018). Development and evaluation of kefir products made with aronia or elderberry juice: Sensory and phytochemical characteristics. Int. Food Res. J., 25 (4), 1373-1383.

EU Novel Food Catalogue. https://ec.europa.eu/food/safety/novel_food/catalogue/search/public/index.cfm (accessed 12.10.2021).

Farag, M. A., Jomaa, S. A., El-Wahed, A. A., El-Seedi, A. (2020). The many faces of kefir fermented dairy products: quality characteristics, flavour chemistry, nutritional value, health benefits, and safety. Nutrients, 12 (2), 346.
Francini, A., Sebastiani, L. (2013). Phenolic compounds in apple (Malus $x$ domestica Borkh.): Compounds characterization and stability during postharvest and after processing. Antioxidants, 2, 181-193.

Fujita, R., Shigeki, J., Hayasaka, T. Matoba, K., Hoshino, Y. (2020). Evaluation of fruit anthocyanin composition by $\mathrm{lc} / \mathrm{ms}$ in interspecific hybrids between haskap (Lonicera caerulea subsp. edulis (Turcz. ex. Herder) Hultén) and miyama-uguisukagura (Lonicera gracilipes Miq.) Hort. J., 89 (4), 343-350.

\section{Fruit Growers News.}

https://fruitgrowersnews.com/news/haskap-seen-by-some-as-the-fruit-of-the-future/ (accessed 12.10.2021).

Güneş, A. B., Aksoy, A. N., A., Kocyigit, A. (2019). The importance of polyphenols as functional food in health. Bezmialem Science, 7 (2), $157-163$.

García-Burgos, M., Moreno-Fernandez, J., Alférez, M. J. M., Díaz-Castro, J., López-Aliaga, I. (2020). New perspectives in fermented dairy products and their health relevance. J. Func. Foods, 72, 104059.

Gołba, M., Sokół-Łętowska, A., Kucharska, A. Z. (2020). Health properties and composition of honeysuckle berry Lonicera caerulea L. an update on recent studies. Molecules, 25, 749.

Grobelna, A., Kalisz, S., Kieliszek, M. (2019). Effect of processing methods and storage time on the content of bioactive compounds in blue honeysuckle berry purees. Agronomy, 9, 860 .

Jurikova, T., Sezai, E., Rop, O., Mlcek, J., Balla, S., Zitnż, R., Sochor, J., Hegedusova, A., Benedikova, D., Ďurišová, L. (2014). The evaluation of anthocyanin content of honeyberry (Lonicera kamtschatica) clones during freezing in relation to antioxidant activity and parameters of nutritional value. Zemdirbyste-Agriculture, 101, 215-220.

Jurikova, T., Rop, O., Mlcek, J., Sochor, J., Balla, S., Szekeres, L., Hegedusova, A., Hubalek, J., Adam, V., Kizek, R. (2012). Phenolic profile of edible honeysuckle berries (genus Lonicera) and their biological effects. Molecules, 17 (1), 61-79.

Miliauskas, G., Venskutonis, P. R., Van Beek, T. A. (2004). Screening of radical scavenging activity of some medicinal and aromatic plant extracts. Food Chem., 85, 231-237.

Nielsen, B., Gürakan, G. C., Ünlü, G. (2014). Kefir: A multifaceted fermented dairy product. Probiotics Antimicrob. Prot., 6, 123-135.

Nguyen, L., Hwang, E. Sun. (2016). Quality characteristics and antioxidant activity of yogurt supplemented with aronia (Aronia melanocarpa) juice. Nutr. Food Sci., 21 (4), 330-337.

OECD 2018. Guidelines on objective tests to determine quality of fruit and vegetables, dry and dried produce.

https://www.oecd.org/agriculture/fruit-vegetables/publications/Guidelines_on_Objective_Tests_2018.pdf (accessed 12.10.2021).

Paaver, U., Matto, V., Raal, A. (2010). Total tannin content in distinct Quercus robur L. Galls. J. Med. Plant Res., 4 (8), 702-705.

Queiroz, V. A. V., Aguiar, A. D. S., de Menezes, C. B., de Carvalho, C. W. P., Paiva, C. L., Fonseca, P. C., Conceiēćo, R. R. P. (2018). A low calorie and nutritive sorghum powdered drink mix: Influence of tannin on the sensorial and functional properties. J. Cereal Sci., 79, 43-49.

Rupasinghe, H. P. V., Arumuggam, N., Amararathna, M., De Silva, A. B. K. H. (2018). The potential health benefits of haskap (Lonicera caerulea L.): Role of cyanidin-3-O-glucoside. J. Func. Foods, 44, 24-39.

Wrolstad, R. E. (1993). Color and pigment analyses in fruit products. Station Bulletin 624. https://ir.library.oregonstate.edu/concern/administrative_report_or_publications/9s1616449 (accessed 12.10.2021).

Sharma, A., Lee, H.-J. (2020). Lonicera caerulea: An updated account of its phytoconstituents and health-promoting activities. Trends Food Sci. Technol., 107, 130-149. 
Singleton, V. L., Orthofer, R., Lamuela-Raventos, R. M. (1999). Analysis of total phenols and other oxidation substrates and antioxidants by means of Folin-Ciocalteu reagent. Methods Enzymol., 299, 152-178.

Sochor, J., Jurikova, T., Pohanka, M., Skutkova, H., Baron, M., Tomaskova, L., Balla, S., Klejdus, B., Pokluda, R., Mlcek, J., Trojakova, Z., Saloun, J. (2014). Evaluation of antioxidant activity, polyphenolic compounds, amino acids and mineral elements of representative genotypes of Lonicera edulis. Molecules, 19 (5), 6504-6523.

Received 22 March 2021

Accepted in the final form 3 November 2021
Šenica, M., Stampar, F., Mikulic-Petkovsek, M. (2018). Blue honeysuckle (Lonicera cearulea L. subs. edulis) berry; A rich source of some nutrients and their differences among four different cultivars. Scient. Hort., 238 215-221.

Tian, Y., Laaksonen, O., Haikonen, H., Vanag, A., Huma E., Linderborg, K., Karhu, S., Baoru Y. (2019). Compositional diversity among blackcurrant (Ribes nigrum) cultivars originating from European countries. J. Agric. Food Chem., 67 (19), 5621-5633.

\section{LONICERA CAERULEA L. KĀ BIOLOG̦ISKI AKTĪVO SAVIENOJUMU AVOTS SKĀBPIENA PRODUKTA BAGĀTINĀŠANAI}

Lonicera caerulea L., pazīstamas arī kā sausserža ogas, ir bagātas ar bioloǵiski aktīviem savienojumiem, kas padara tās par vērtīgu izejvielu funkcionālas pārtikas izstrādei. Pētījuma objekti bija trīs sausserža ogu šķirnes ('Zoluška', 'Siṇaja Ptica', 'Goluboje Vereteno'), četri genotipi (Nr. 2A; Nr. 3; Nr. 5; Nr. 8) un skābpiena produkts (kefīrs), kas tika bagātināts ar atškirīgiem (3-10\%) daudzumiem augḷu biezeņa. Lai noteiktu izejvielu un produktu kvalitatīvos rādītājus, tika veiktas fizikālās un kīimiskās analīzes. Kefîra patikšanas pakāpe tika novērtēta ar sensoro analīžu palīdzību, izmantojot 9-punktu hedonisko un līnijskalu. Iegūtie rezultāti rāda, ka starp škirnēm vislielākais antocianīnu (1103,5 mg CGA·100 $\left.\mathrm{g}^{-1}\right)$, kopējo fenolu (693,3 mg GAE·100 $\left.\mathrm{g}^{-1}\right)$, flavonoīdu $\left(753,9 \mathrm{mg} \mathrm{CAE} \cdot 100 \mathrm{~g}^{-1}\right)$ un tanīnu $\left(1,6 \mathrm{mg}\right.$ TAE $\left.\cdot 100 \mathrm{~g}^{-1}\right)$ saturs ir sastopams 'Siņaja Ptica' ogās. Starp genotipiem visvērtīgākās bija genotipa Nr. 8 ogas. Abiem paraugiem noteikta arī visaugstākā antiradikālā aktivitāte: ar $\mathrm{ABTS}^{+\bullet}$ vidēji $71,7 \%$ un ar $\mathrm{DPPH}^{-}$- 43,7\%. Pēc sensoro analīžu rezultātiem visaugstāk tika novērtēts kefïrs ar $10 \%$ sausseržu ogu biezena piedevu. Sausserža ogas varētu izmantot kā daudzsološu dabisko antioksidantu avotu turpmākajos pētījumos ar mērḳi izstrādāt dažādus jaunus produktus, kas varētu apmierināt patērētāju vēlmes. 